\title{
Netflix Filmlerinde Kadın Anlatısı: Marriage Story Filminin Feminist Kuram Bağlamında İncelenmesi
}

Başvuru Tarihi: 21.02.2021 Yayın Kabul Tarihi: 12.04 .2021 Yayınlanma Tarihi: 30.04 .2021

\author{
Yelda Yanat Bağcı ${ }^{1}$ \\ Hasan Kalyoncu Üniversitesi, Iletişim Fakültesi, \\ Radyo, Televizyon ve Sinema Bölümü, Gaziantep \\ yeldayanat@gmail.com \\ (iD) ORCID: 0000-0001-9586-7130
}

\begin{abstract}
Öz
Sinema güzel sanatların en genci, günümüzün en popüler sanat dalı ve en etkili kitle iletişim araçlarından olma özelliklerinden dolayı toplumsal bakışı hem etkiler hem de ondan etkilenir. İcat olduğu günden itibaren, egemen olan ataerkil ideolojinin topluma empoze ettiği toplumsal cinsiyet rollerini sürekli olarak yeniden üreten ve bu rollerin pekişmesi için büyük görev üstlenen sinema, özellikle 2. Dünya Savaşı sonrası başlayan toplumsal değişimle ve 70'li yıllardaki kadın hareketlerinin yaygınlaşmasıyla hem içerik hem de bu içeriğin işleniş biçimi açısından dişil olan kadın anlatısı ile tanışmıştır. Günümüzde klasik anlatı sinemasının hala stereotiplerle karşımıza çıkarmaya devam ettiği kadın ancak kadın anlatısının kullanıldığı alternatif filmlerde ikincil olmayan bir biçimde yansıtılmaktadır.

Bu çalışmada "Marriage Story" filmi günümüzün en büyük film üreticilerinden Netflix'in yayın politikalarını oluştururken kadın anlatısına nasıl yaklaştığını irdelemek amacıyla feminist kuram bağlamında incelenmiştir. Bu amaçla ana karakterlerin nasıl sunulduğu, hangi mekanlarda gösterildiği kadın anlatısı ve dişil film dili çerçevesinde analiz edilmiştir. Yapılan inceleme sonucunda filmin, ataerkil ideolojinin dayattığı toplumsal cinsiyet rollerini yeniden üretmediği görülmüş; feminist filmlerin en temel çıkış noktası olan kadını özne olarak sunması, öldürücü cezbeden izlenirlik nesne (femme fatal) ya da kurban olarak yansıtmaması, güçlü, özgür ve kendi seçimlerini yaşayan film kişisi olarak işlemesi ve özel alana hapsetmeyip kamusal alanlarda göstermesiyle kadın anlatısı oluşturduğu ve anlatımında dişil bir dili tercih ettiği tespit edilmiştir.
\end{abstract}

Anahtar Kelimeler: Feminist kuram, kadın anlatısı, Netflix, sinema, Marriage Story.

\footnotetext{
${ }^{1}$ Doktor Öğretim Üyesi
} 


\title{
Women's Narrative in Netflix Films: A Study of Marriage Story in the Context of Feminist Theory
}

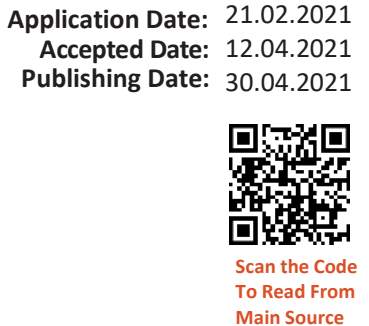

\author{
Yelda Yanat Bağcı' \\ Hasan Kalyoncu University, Faculty of Communication, \\ Department of Radio, Television and Cinema, Gaziantep \\ yeldayanat@gmail.com \\ (iD) ORCID: 0000-0001-9586-7130
}

\begin{abstract}
Because cinema is the youngest of the Fine Arts and the most popular art branch of today and one of the most influential mass media, it both affects and is influenced by the social view. Cinema, which constantly reproduces the gender roles that the dominant patriarchal ideology imposes on society and plays a major role in strengthening these roles from the day it was invented, has been introduced to the female narrative, which is feminine both in terms of content and the way it is processed, especially with the social change that began after the Second World War and the spread of women's movements in the 70s. Today, the woman that classic narrative cinema still continues to encounter with stereotypes, is reflected in a non-secondary form in alternative films where the female narrative is used.

In this study, the film "Marriage Story" was examined in the context of feminist theory in order to examine how Netflix, one of today's largest filmmakers, approaches the female narrative when creating its broadcast policies. For this purpose, how the main characters are presented, in which places they are shown, has been analyzed within the framework of the female narrative and the feminine film language. The review found out that the film did not reproduce the gender roles imposed by patriarchal ideology. It has been found that the film creates a female narrative and prefers a feminine language in terms of presenting women as subject, not reflecting women as victim or femme fatal, processing her strong, free and living her own choices, and not imprisoning her in private space, but also showing in public spaces.
\end{abstract}

Keywords: Feminist theory, women's narrative, Netflix, cinema, Marriage Story.

\footnotetext{
${ }^{2}$ Assistant Professor
} 
,

Cilt: 04 - Sayı: 01

\section{Giriş}

Sanatı toplumdan, toplumsal olandan, toplumu da sanattan ayrı tanımlamak çok zor. Sinemayı ise ister fotoğrafik kayıt yapan ve bu görüntüleri hareketli şekilde yansıtan bir kitle iletişim aracı, ister film üretme sanatı olarak tanımlayalım; her iki tanımda da eksik kalan yer sinemanın toplum ve toplumsal değişimle olan etkileşimidir (Adanır, 2006). Bu etkileşim, her türlü toplumsal kavramı kapsamakla birlikte, özellikle toplumsal cinsiyet gibi doğal olmayan ve toplumlara sonradan öğretilen bir kavramın belleğimize, kültürümüze ekilebilmesinin yanı sıra kadının yerinin, işlevinin ve erkekle, iktidarla ilişkilerinin biçimlendirilmesi, öğretilmesi ve sürdürülmesi açısından çok önemlidir. Bu anlamda sinema hiç şüphesiz toplumsal cinsiyet rollerinin yeniden üretilmesi konusunda ataerkil ideolojinin en sık başvurduğu araçtır. Bu yüzdendir ki sinema filmleri yüzyıldır hep erkek egemen bir bakış açısıyla, kurban, sadece arzulanmaya değer, erkekle olan ilişkisine ya da iyi anne-eş olma becerisine göre hayatta bir konum kazanan, ikincil kadın temsillerini karşımıza çıkarmıştır.

John Berger'in deyimiyle "Kadının erkeklere nasıl göründüğü, onun yaşamında başarı sayılan şey açısından çok önemlidir...Böylece kadın kendini bir nesneye, özellikle görsel bir nesneye, seyirlik bir şeye dönüştürmüş olur. "(2014, s. 46). Bu görüşe karşı çıkan ve kadının bu tanımının değişmesi gerektiğini söyleyen feminist düşünce 1960'larla birlikte güçlenen ve özellikle 68 hareketlerinin özgürlükçü havasıyla tüm dünyaya yayılan bir eleştiridir ve aslında temelinde iktidar eleştirisidir. Hükmeden ile baskı altına alınanı tarihteki en eski baskılanan yani kadın üzerinden teşhir etme amacını güden feminist eleştiri, bu amaçla kadının sinemadaki temsilini de analiz etmeye ve derinlemesine tartışmaya başlamıştır.

Her ne kadar günümüzde üretilen filmlerin çoğuna hala erkek egemen bir bakış açısı hakim olsa da feminist sinema 50 yıl içinde birçok film üreticisini etkilemiş ve sonucunda da kadını öznesi yapan pek çok film üretilmiştir. Günümüzde ise alternatif anlatımı desteklediğini ve toplum tarafından ikincil olarak kabul edilen, görmezden gelinen tüm grupların hikayelerine öncelik verdiğini söyleyen Netflix kadın hikayelerine yayın akışında oldukça geniş bir yer ayırmaktadır. Bu bağlamda Netflix'in kadın anlatısını temsil eden, oldukça ses getirmiş, bol ödüllü filmi "Marriage Story", ataerkil ana akım sinemaya alternatif bir bakış açısıyla; kadını özne olarak işlemesi ve filmde kadını kamusal alanda, varlık sahibi, güçlü, yazgısını ele alan, mücadeleci ana karakter olarak göstermesi sebebiyle bu çalışmanın konusu olarak seçilmiştir. Bu doğrultuda "Marriage Story" filmi eleştirel feminist kuram bağlamında nitel araştırma yöntemlerinden anlatı analizi ve içerik analizi yöntemleri kullanılarak incelenmiştir. Anlatı analizinde mekan, kişiler ve zaman analiz edilir. Bu çalışmada kadının mekânsal sunumu ve kişiler anlatı analizi yöntemiyle incelenmiştir. Filmin zaman kullanımında anlatımı veya içeriği etkileyecek herhangi bir özellik olmadığından; filmde zaman şimdiki zaman olarak ve doğrusal aktığından zaman öğesinin incelenmesine gerek görülmemiştir. İçerik analizinde ise gözlem yoluyla elde edilen veriler belirli kavram ve temalar altında yorumlanır (Neuman, 2012, s. 663). Bu çalışmada söz 


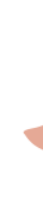

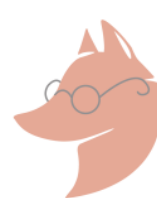

Cilt: 04 - Sayı: 01

konusu kavram ve temalar feminist film eleştirisinin başlıca konuları olan "kadının arzulanan nesne olarak işlenmesi", "kadının ikincil karakter olarak ele alınması", "kadının konumunun ve değerinin erkeğe göre belirlenmesi", "kadının kamusal alandan soyutlanması", "toplumsal cinsiyet rollerinin yeniden üretilmesi", "kadının kurban olmayı kabul edip kaderine razı gelmesi" olarak belirlenmiş ve filmin içeriği bu kavramları ele alış biçimi açısından analiz edilmiştir.

\section{FEMINIST FILM KURAMI VE SINEMA}

Latince'de kadın anlamına gelen 'femine'den türeyen feminizm, en geniş tanımıyla kadınların kadın olma durumundan dolayı her alanda uğradığı haksızlıklara, ataerkil ideolojinin kadın üzerinde uyguladığı her türlü dayatma ve baskıya karşı çıkan, kadın dayanışmasıyla cinsiyetçi politikalara karşı mücadele veren bir kadın hareketidir (Sevim, 2005). Feminist düşünce her ne kadar sadece kadın ve erkeğin toplumsal cinsiyet rollerine eleştirel bir yaklaşım olarak algılansa da aslında onun esas meselesi iktidar ve onun eşitliksiz ilişkileridir. Bu bağlamda feminizmi bir toplumsal eleştiri, var olan sisteme bir baş kaldırış olarak tanımlamak daha doğru olacaktır. Temelinde kadını yok sayan her çeşit eril söylemi eleştiren bu yaklaşım aynı zamanda siyasal, toplumsal, ekonomik ve kültürel her türlü alanda kadının erkekle eşitliğinin sağlanması amacını gütmektedir.

Toplumsal cinsiyet rolleri topluma birçok araç tarafından iletilir ve nesiller boyu çeşitli yollarla tekrarlanarak pekiştirilir. Bundan binlerce yıl önce toplumsal cinsiyet rollerinin masallar, destanlar, ritüellerle iletildiğini biliyoruz; günümüzde ise bu öğretinin en güçlü araçlarından biri hiç kuşkusuz sinemadır. Kadının kadın gibi erkeğin ise erkek gibi olması gerekliliği bize izlediğimiz hemen her filmde tekrar tekrar anlatılmaktadır. Bu filmlerde kadın veya erkek olmanın özellikleri ve gereklilikleri çeşitli göstergelerle seyirciye iletilir. Feminist film teorisinin önemli isimlerinden Claire Johnston bu durumu kadının sinemada hiçbir zaman kadın olarak kendini temsil etmediği şeklinde açıklamıştır. Ona göre kadınlar erkek olmama özellikleriyle filmde var olurlar. Kadının taşıdığı özellikler de yine erkeğin özelliklerine göre şekillenir (Cook, Berning, 2005, s. 353). Buna örnek olarak filmlerde kadının duygusallığı yanında erkeğin akılcılığı, kadının tek eşli olması gerekirken erkeğin çok eşliliği, kadının yeri evken erkeğin her türlü kamusal alanda ve özgür olması, kadının kurban erkeğin kahraman olması gibi birçok durum sıralanabilir. Burada kadın olan doğa ile eril olan kültür ile özdeşleştirilmiş ve doğanın kültüre egemen olması, erkeğin kadına egemen olması olarak yorumlanmıştır. İnsanoğlunun gelişip doğaya hakim olası, onu kullanılan bir araç olarak şekillendirmesi kadının toplumsal konumunu da değiştirmiştir. Artık doğa yani kadın eski gücünde ve etkisinde değildir, dolayısıyla kültür yani eril olan doğayı şekillendirir. Böylece eril söylemi ileten kültür kadını ötekileştirmiştir (Çağlıyan, 2014, s. 254). Simone de Beauvoir'in “ikinci cinsiyet” diye tanımladığı "kadınlık" ise sadece farklılıktır, ötekililiktir. Kadın erkeğin ötekisidir, burada özne olan her zaman erkektir. Bu nedenle de kadının konumu her zaman erkeğe göre belirlenir. Ona 
göre: "Kadın doğulmaz, kadın olunur. Hiçbir sosyolojik, psikolojik ya da ekonomik yazgı yoktur ki, dişi insanın toplumda büründüğü figürü belirlesin... "(1952, s. 249). Bu genele yayılan eril düşünce biçimi elbette sinemada da kendini göstermiştir. Kadın sinemada hep ikinci cinsiyet olarak kalmış ve onun için belirlenmiş olan toplumsal cinsiyet kalıplarının dışına çıkamamıştır. Seyirci de doğal olarak bu edilgen, güçsüz dişil karakterler yerine hikayenin merkezinde yer alan, kusursuz, ideal kahraman erkeklerle özdeşleşir. Bu da izleyicinin filmleri hep erkeğin gözünden, eril bir bakış açısıyla takip etmesine neden olur.

Sinemanın ilk yıllarından itibaren kadınlar sinemada hep aynı stereotiplerle (kalıp yargı) temsil edilmiş, erkeklerin temsilleri ise sürekli gelişmiş ve değişmiştir. illk filmlerden beri kadın karakterler sadece ana erkek karakterin hayatında üstlendikleri rolleri kadar değerli olmuştur. Genellikle ana erkek karakterin eşi, ana erkek karakterin sevgilisi, annesi ya da çocuğu olmaktan başka bir işlevleri yoktur. Onlar ana erkek karakterin yolculuğunda içi boş, kendi hikayeleri olmayan, boşluk doldurucu birer unsurdan ibarettir. Toplumsal hayatta olduğu gibi kadın sinemada da ikincildir, ötekidir. Hollywood Sineması gibi ticari film üreticileri Avrupa Sineması gibi sanatsal filmi üreticilerine oranla bu stereotiplere çok daha fazla ve daha uzunca bir süre bağlı kalmıştır (Johnston, 1973, s. 2). Hollywood Sineması'nın başını çektiği klasik anlatı sinemasında kadın sadece bakılması arzulanan bir kurbandır. Feminist sinema kuramının en önemli teorisyenlerinden Laura Mulvey burada kadını bakılası pasif nesne konumunda tanımlarken erkeği bakmaktan haz alan yani aktif olarak betimlemiştir. Bu tanımı yaparken psikanalizden ve Freud'un skopofili (başkalarına bakmaktan duyulan haz) kavramından yararlanan Mulvey'e göre filmdeki kadın hem bakılan hem de teşhir edilendir (1975). Aynı zamanda seyirci zaten ana karakter olan erkekle özdeşleşeceği için bu kurbana bakarken ve onu röntgenlerken suçluluk da hissetmez. Çünkü bu kadınların ana işlevi zaten teşhir edilmek ve arzulanmaktır. Klasik anlatı sinemasının bu anlamda yarattığı en ünlü stereotip hiç tartışmasız aptal sarışın mitidir. Marilyn Monroe'nin başını çektiği ve sinema tarihinde defalarca kullanılan bu aptal seks tanrıçası miti Hollywood filmlerinde görsel ve erotik etki amacıyla kullanılmıştır (Öğüt, 2009, s. 209).

Kadınların sinemada eril bir dille ve ikincil karakter olarak yer alması sadece hikaye içeriklerinden değil film afişlerinden de saptanabilir. Feminist düşüncenin etkilerinin en güçlü görüldüğü 60'lı yıllara gelene kadar klasik anlatı sinemasının afişleri incelendiğinde kadınların afişlerin çoğunda ya hiç yer almadığı ya da kadın oyunculara çok az yer ayrıldığı gözlemlenir. Senaristler, yönetmenler ve hatta afiş tasarımcıları kadınları görmezden gelmiş, onları filmlerde bakılmaya değer dolgu malzemesi olarak kullanmışlardır. Ayrıca filmlerde yer alan kadın oyuncuların en seksi kıyafetlerini giydikleri sahnelerden alınmış bir fotoğrafları karton maket olarak sinema salonlarının girişine koyulmuş ve böylece seyircinin ilgisinin artması amaçlanmıştır. Özellikle 1930- 1960 yılları arasını kapsayan dönemde Hollywood Stüdyoları'nda üretilen ve klasik anlatı sineması diye adlandırdığımı sinema geleneği kadını hep evde, kamusal alandan soyutlanmış, anne, iyi eş, kurban olarak sunmuştur. 2. Dünya Savaşı'nın 
başlaması ve orduya katılan askerlerden boşalan işlere kadınların geçmesiyle birlikte, kadınlar hak ve özgürlüklerini konuşmaya başlayınca, bazı Hollywood filmlerine de ilk kez evin dışında, iş hayatında kadın karakterler girmiştir (Kuhn, 1991, s. 89). O dönemde en çok konuşulan filmlerden biri olan Ömre Bedel Kadın'da savaştan sonra işlerini bırakmak istemeyecek kadınlarla, geri dönüp işlerini geri almak isteyecek erkekler arasında doğabilecek muhtemel çatışma konu alınmıştır. Filmdeki ana karakter kocasından ayrılıp ekonomik özgürlüğünü kazanan bir kadınındır. Hollywood Sineması açısından oldukça yenilikçi olan bu film karakterin başına gelen felaketler sonucunda kadının bir katile, bir canavara dönüşmesiyle sona erer. Bu anlamda kadının özgürleşmesinin, sınırlarını kabul etmemesinin sonucu da felaketten başka bir şey değildir (Ryan, 2012, s. 235). Kadının özgürleşmek için şiddete başvurması birçok feminist filmde karşımıza çıkan bir olgudur. Aslında buradaki temel direniş daha önceki kurban rolünedir. Kadınların hep ezilen, hep şiddete maruz kalan ve başkaldırmayan, yazgısını kabul eden temsiline karşı feminist sinemacılar kadını özgürlüğünü ve hayatının kontrolünü kazanmak için her türlü yola başvuran, savaşçı bir karakter olarak göstermeyi seçmiştir. Daha sonra 68 hareketleriyle birlikte tüm dünyayı saran özgürlük düşüncesi kadın hakları alanına da sıçramış ve özellikle kadın sanatçılar yapıtlarını kim için ve ne amaçla ürettiklerini sorgulamaya başlamışlardır (Desjardings, 1988, s. 49). Bu dönem 70'lerle başlayan ve kadının sinemadaki temsilinin ciddi bir şekilde değişmesine neden olan sürecin de başlangıç ateşini yakmıştır. 68 hareketlerinin başkaldırma, özgürleşme, sistemi değiştirme düşünceleri Hollywood'daki kadın yönetmen ve senaristleri de derinden etkilemiştir. Aynı zamanda bu dönemde yine feminist düşünceden doğan kadın dayanışması yani "kız kardeşlik" fikri, baskı ve eşitsizlik karşısında kadınların kardeşliği anlamına gelmektedir. Bu fikir kadınların kadın olma durumuyla ilgili ortak çıkarlarını savunarak erkek egemenliğine karşı her alanda güçlü bir muhalefet olmalarını sağlamıştır (Berktay, 2013, s. 6). Bu düşünce akımlarından etkilenen Hollywood'daki kadın senarist ve yönetmenler de yine bu dönemde kadın karakterleri ezilen rolünden çıkartarak, onları ilk defa farklı öyküler içinde yazmaya başlamışlardır. Bunun sonucu olarak özellikle 19701980 arası çekilen feminist filmlerde kadın ana karakterlerin çoğunun terörist, banka soyguncusu, katil, mafyayla çatışan anne gibi sisteme başkaldıran ve bunu şiddete başvurarak yapan kadınlar olduğunu söylememiz mümkün (Smelik, 2008, s. 105).

Feminizm "öteki" olarak kadının toplumsal cinsiyet rollerini ve kadın erkek ilişkilerinin sadece erkeğin özne olduğu bir biçimde şekillenmesini kabul etmeyen, her türlü eril söylemi eleştiren bir yaklaşım olduğuna göre feminist sinema da kadını bu karşıt bakış açısıyla yansıtan sinemadır diyebiliriz. Burada altı çizilmesi gereken nokta kadınlar tarafından yapılmış her filmin feminist yaklaşımla yapılmış bir film olmadığıdır. Günümüzde makalemize konu olan Marriage Story örneğinde olduğu gibi pek çok erkek yönetmen feminist söyleme yakın filmlere imza atabilirken birçok kadın sanatçı da genel geçer eril söylemleri tekrar eden filmler üretebilmektedir. Buradaki en büyük ayrımlardan biri feminist sinemada öznenin kadın olmasıdır. Feminist filmlerde kadın artık ikinci karakter olmaktan çıkmış, filmin ana karakteri olmuştur. Kendi kararlarını veren, özgürleşmek isteyen, seçimleri için mücadele eden, erkeğin kendine çizdiği 


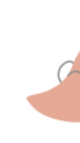

Cilt: 04 - Sayı: 01

\section{MEDIIAJ}

yazgıya boyun eğmeyen, eşit karar yetkisi ve yaşam hakkına sahip kadın film karakterleri feminist anlatının da temelini oluşturur.

Özetle feminist anlatı; biçimini dişil bir dil üzerine oluşturan, hikayeyi kadın bakış açısıyla sunan, ana karakterinin ya da ana karakterlerinden en az birinin kadın olduğu, toplumsal cinsiyet kalıplarını sorgulayan, kadını sadece arzu nesnesi olması ya da bakılabilirliği üzerine inşa etmeyen, kadını erkek üzerinden tanımlamayan, kadının cinselliğini sadece arzulanan ve karşılığında başka bir şey istemeyen kalıbından çıkartıp özgürleştiren, sadece erkek seyirciye değil kadın seyirciye de yönelik içerik üreten, dramatik bir yapısı olan, eleştirici, sarsıcı, yeniden inşa edici, alternatif bir anlatıdır. Feminist anlatıda artık yazgısının akışını kendi kontrolü altına alan kadın hikayede de öznedir. Bu özne onu ikincil konuma itmeye çalışan eril iktidara karşı çıkar ve kendi seçimlerini gerçekleştirmeye çalışır. Bu akış aynı zamanda seyircinin artık kadın ile özdeşlemesini ve kadının bakış açısından dünyayı algılamasını amaçlar.

\section{Netflix Ve Kadın Anlatısı}

Reed Hastings ve Marc Randolp adında iki girişimci tarafından posta yoluyla DVD kiralama şirketi olarak kurulan Netflix, 2003 yılında sadece Amerika'da 1 milyon üyeyi geçerek bu konuda bir rekora imza atmıştır. Şirket 2006 'da 5 milyon üye ile ilk online film ve dizi izleme platformunu hizmete sokmuştur (Randolf, 2019, s. 38). 2012 yılına gelindiğinde 25 milyon üye sayısına ulaşmıs olan Netflix ilk kendi yapımı olan, stand-up gösterisi Bill Burr: You People Are All The Same'i çekmeye başlamıştır. 2013 yılında "House of Cards", "Hemlock Grove", "Arrested Development" ve "Orange is the New Black" isimli 4 orjinal Netflix dizisi ile dizi yapımcılığına başlamış, bu dizilerden "House of Cards" 3 Emmy Ödülü alarak dijital bir platform tarafından üretilip ödül alan ilk dizi olmuştur. 2014'te Netflix ilk kez bir uzun metraj filmin yapımcılığını üstlenmiştir. 2017'de 100 milyona ulaşan üye sayısıyla ilk Oscar Ödülü’nü “The White Helmet" isimli filmle almıştır. 2018'de Emmy'ye en çok aday olan yapımcı sıfatıyla bu ödüllerden 23'ünü kazanmıştır. 2019'da 2 Oscar ödülü almış ve ilk animasyon filmi "Klaus"u yapmıştır. 2020'de Oscar Ödülleri'ne en çok aday olan stüdyo ünvanına ulaşan Netflix'in Covid 19'dan ekonomik olarak etkilenen Sinema TV sektör çalışanlarını desteklemek için kurduğu bir vakfı vardır ve gelirlerinin yüzde ikisini siyahi toplulukların desteklenmesi için bağışlamaktadır ${ }^{3}$.

1997 yılında Marc Randolp isimli Amerikalı girişimcinin bir DVD'yi kendine postalayarak başlattığı Netflix macerası bugün dünyanın en büyük film üreticilerinden birine dönüşerek devam etmekte. Günümüzde dünyadaki internet trafiğinin yüzde $15^{\prime}$ ini tüketen Netflix, Amerika'da en yoğun izlenme saatlerinde yüzde $40^{\prime}$ lara kadar çıkan izlenme rakamları ve 150 farklı ülkede sürdürdüğü yayıncılık ve yapımcılık faaliyetleriyle hiç şüphesiz sinema sektörünün en büyük aktörlerinden biridir. 2007'de Cannes Film Festivali'nde bir Netflix filmi olan Okja'nın gösterimi sırasında Netflix logosunun belirlemesiyle salondaki seyircilerin filmi yuhalamaya

\footnotetext{
${ }^{3}$ https://about.netflix.com/en
} 


\section{MEIDIAJ}

başlaması her ne kadar uzunca bir süre özellikle sanat filmi üreten yönetmenler ve büyük film festivallerinin jürileri tarafından dijital bir platformun ürettiği filmler sanat filmi sayılabilir mi tartışmalarını başlatmış olsa bile, Netflix bugün gerek üretim içindeki payı gerekse ürettiği filmlerin kalitesi göz önünde bulundurularak bu tartışmaları geride bırakmış gibi görünmektedir (Vielen, 2018).

Kendine özgü içerikleri üretmeye başladığı günden beri toplum tarafından ikincil olarak görülen her türlü guruba film ve dizilerinde yer veren ve daha önceki film üreticilerinin görmezden geldiği eşcinsellerin, göçmenlerin, siyahilerin ve özellikle de kadınların hikayelerine odaklanan Netflix'in içerik sorumlusu Ted Sarandos verdiği bir röportajda bu bağlamda hikayelerin anlatılma biçimini kökten değiştirdiklerini ifade etmiştir. Bunu yapabilmelerinin en büyük sebebi elbette Netflix'in diğer medya kuruluşlarından çok daha özgür olmasıdır. Zira Netflix üyelik ücretleriyle sermayesini oluşturmakta ve bu sebeple reklam verenlerden ya da üzerinde herhangi bir içerik baskısı oluşturacak otoriten bağımsız bir şekilde yayın akışına karar verebilmektedir (Sim, 2016, s. 190).

Netflix özellikle güçlü kadın karakterlerin hikayelerini işleyen filmler üretmiş ve kadın konusunu merkeze alan belgeseller yayınlamıştır. Bunların başlıcaları olarak $70^{\prime}$ lerdeki feminist hareketlerin gündelik hayatı nasıl etkilediğini içlerinde Jane Fonda ve Lily Tomlin gibi oyuncuların da bulunduğu bir düzine feministin deneyimleri üzerinden anlatan "Portreits of Feminism" belgeseli, Hindistan'da hijyenik pede ulaşımı olmayan kadınların ve genel olarak Hindistan'da kadının regl dönemine bakış açısının ele alındığı kısa belgesel "Period.End of Sentence", Beyonce'nin siyahi bir kadın olarak pop star olma yolculuğunun zorluğunu anlattığı "Homecoming: A Film By Beyonce" belgeseli, Terry ve Pat isimli iki lezbiyenin toplum baskısı yüzünden saklamak zorunda kaldıkları aşk hikayelerini konu alan "A Secret Love" belgeseli, kadın ilişkilerinin ve kadın sorunlarının tamamı kadın mahkum olan karakterlerin öyküleri üzerinden anlatan "Orange is The New Black" dizisi, siyahi bir kadın olarak Michel Obama'nın verdiği mücadeleleri ve dokunduğu diğer siyahilerin yaşamlarını anlatan "Becoming" belgeseli, çok eşli bir hayatı benimseyen siyahi kadın karakter Nola'nın hayatını komedi unsurlarıyla ekrana yansıtan "She's Gotta Have It", 1920'lerde İspanya'da iş hayatına girmeye ve erkeklerle eşit haklara kavuşmaya uğraşan 4 kadın feministin hikayesinin anlatıldığı "Cable Girls", kadın sorunlarını esprili bir dille iki dişi kuşun hayatı üzerinden yansıtan "Tuca \& Bertie" animasyon dizisi, 2018 Amerikan seçimlerinde aday olan kadınların siyasi mücadelesini anlatan "Knock Down The House" belgeseli, cinsel tacize uğrayan kadınların hikayelerine odaklanan "Audrie \& Daisy", 2. Dalga feminizm hareketini dönemin önemli kadın figürlerini merkeze alarak anlatan "Feminsts: What Were They Thinking?" belgeseli, güzellik yarışması için kayıt olan ve kendine güvenen kilolu bir genç kız üzerinden kadınların vücut algısını pozitif yönde etkilemeye çalışan "Dumplin", babasından kalan şirketi devralan siyahi kadın karakter Adaeze'in erkeklerin dünyasında var olma savaşını anlatan "Lionheart", farklı etnik kökenlerden farklı kadınların kozmopolit bir şehirde hayallerinin peşinden gitmesini anlatan "The Incredible Jassie James" ve 
makalemizin de konusu olan, sevdiği erkeğin hayatı için kendi hayatından, ideallerinden vazgeçmiş bir kadının boşanma ve hayatının kontrolünü tekrar eline alma hikayesini anlatan "Marriage Story" olarak sıralanabilir. Sözünü ettiğimiz örnekler ve çok daha fazlası bize Netflix'in içerik politikalarının kadın sorunları ve kadının toplumsal cinsiyet eşitliği konularına oldukça önem verdiğini gösteriyor. Bu film, dizi veya belgesellerde işlenen karakterlerin sadece kadın olma durumundan dolayı değil aynı zamanda farklı coğrafyalardan farklı kadınların göçmen-kadın, siyahi-kadın, kilolu-kadın, dul-kadın, çok eşli-kadın, feminist-kadın, iktidar sahibi-kadın olmak gibi toplumsal cinsiyet kalıplarının çok dışında bir takım özellikler barındırdıklarını söylemek mümkün. Bu bağlamda hem kadın bakış açısını yansıtan içerikleri üretmesi hem de yapımcı, yönetmen ve senaristlerinin kadın olduğu filmleri çokça yayınlaması yönünden Netflix'in kadın anlatısına yayın içeriğinde oldukça fazla yer verdiğini, yayın politikalarını ve programlamalarını oluştururken kadın anlatısını içeren filmlere pozitif ayrımcılık yaptığını söylemek yanlış olmaz.

\section{MARRIAGE STORY FILMININ FEMINIST KURAM BAĞLAMINDA INCELENMESI}

\section{Film Hakkında}

Başrollerini Adam Driver, Scarlett Johansson ve Laura Denn'in üstlendiği 2019 yapımı 2 saat 17 dakikalık Marriage Story filmi, senaryo yazımını ve yönetmenliğini Amerikan Bağımsız Sineması'nın önde gelen isimlerinden Noah Baumbach'ın yaptığı bir dramadır. Dünya prömiyerini Venedik Film Festivali'nde yapan film aynı yıl dünya çapında aday olduğu 257 ödülden bir tanesi Oscar olmak üzere toplam 126 tanesini alarak hiç kuşkusuz son yılların en çok konuşulan filmlerinden biri olmuştur. Film aynı zamanda Bafta ve Altın Küre Ödülleri'ne aday olan ilk Netflix filmi olma özelliğini taşımaktadır ve 2020 yılında Amerikan Film Endüstrisi Vakfı, Amerikan Ulusal İnceleme Kurulu ve Time dergisi tarafından yılın en iyi 10 filmi arasında gösterilmiştir. Filmin bu kadar ilgi görmesinin ve konuşulmasının temel sebepleri aldığı ödüllerin yanı sıra oyunculuklarındaki ve diyaloglarındaki doğallık, (Diyaloglar o kadar doğaldır ki çoğu seyirci diyalogların doğaçlama olduğunu düşünmüştür ancak bu doğru değildir. Oyuncular birebir senaryoda yazan diyalogları oynamıştır.) ve hiç şüphesiz Baumbach'ın evlilik ve boşanma mevzusuna gerçekçi, samimi ve duygusal yaklaşımıdır. Bu gerçekçiliğin ve samimiyetin temel sebebi Baumbach'ın senaryoyu yazarken 2013 yılında boşandığı oyuncu eşi Jennifer Jason Leigh ile yaşadığı gerçek deneyimlerden ilham almasıdır. Baumbach'ın başrol oyuncusu olarak Scarlett Johansson'ı tercih etmesinin en önemli nedenlerinden biri ise Johansson'ın filmin çekildiği dönemde ikinci eşinden boşanma sürecinde olmasıdır. Filmdeki farklı birçok unsur yine Baumbach'ın gerçek hayatıyla paralellik gösterir. Örneğin Scarlett Johansson'ın ve Baumbach'ın da boşanma davalarını yürüten ünlü boşanma avukatı Laura Wesser filmde avukat Nora karakteri olarak karşımıza çıkar. Ayrıca Baumbach gerçeklik duygusunu arttırmak için gerçek mekanları kullanmayı tercih etmiştir. Örneğin Nora'nın ofis sahneleri Laura Wesser'in kendi ofisinde, arabuluculuk sahneleri gerçek arabulucu ofisinde çekilmiştir. 


\section{MEDIAJ}

\section{Filmin Öykü Akışı}

Film, evli bir çift olan Charlie (Adam Driver) ve Nicole (Scarlett Johansson) Barber'ın birbirleri hakkında sevdiği şeyleri sıraladıkları dış ses ile başlar. Bu, asında yaklaşan boşanma davaları öncesinde başvurdukları arabulucunun kendilerine verdiği bir egzersizdir ve arabulucu bu yöntemle onlara ilk etapta birbirlerine neden aşık olduklarını hatırlatmaya çalışmaktadır. Arabulucu yazdıkları listeleri sesli bir biçimde birbirlerine okumalarını istediğinde, Nicole öfkeyle karşı çıkar, okumak istemediğini söyler ve dışarı fırlar. Aslında ikisi de oğulları Henry'nin en az etkileneceği şekilde evliliklerini sonlandırmayı istemektedir. Bu nedenle aralarında avukat tutmama konusunda anlaşmış ve onun yerine bir arabulucuya başvurmuşlardır.

Çift New York'ta yaşamaktadır. Aynı zamanda burada Charlie'nin yönetmeliğini yaptığı ve Nicole'ün de oyuncu olduğu bir tiyatro toplulukları vardır. Bu topluluk en başta o dönemde Charlie'ye oranla daha ünlü olan Nicole'ün sayesinde başarı kazanırken, zamanla Charlie tiyatro yönetmenliğindeki başarısı sayesinde ön plana çıkmış ve Nicole'ün ünü ise sönmüştür. Bütün bu süreçten rahatsız olan ve kariyerini tekrar rayına sokmak isteyen Nicole yeni başlayacak bir TV dizisinin deneme bölümünde oynaması için teklif alır. Ancak bu yeni iş teklifi ikili arasında da yeni bir gerilimi doğurur, çünkü dizinin çekimleri Los Angeles'te yapılacaktır. Bu sırada Charlie de oyununu Broadway'e taşıması için önemli bir teklif almıştır. ỉkili Henry'nin yaşayacağı şehir hakkında kararı deneme çekimi sonrasına erteler. Keza dizinin beğenilip beğenilmeyeceği henüz belli değildir. Nicole Henry'yi de yanına alarak dizinin çekimleri için Los Angeles'a, annesi Sarah'ın evine gider.

Nicole Los Angeles'ta çekimler sırasında tanıştığı yapımcının ısrarı üzerine ünlü boşanma avukatı Nora Fanshaw'a (Laura Dern) başvurur. Charlie ile avukat tutmama konusunda anlaştıkları için bu durumdan oldukça rahatsız olan Nicole, Nora'nın yönlendirmeleri sonucunda rahatlar ve ona kendi hikayesini anlatır. Nicole 20 yaşındayken onu ünlü eden cinsel içerikli bir filmde oynamıştır. Bu süreçte aynı zamanda kendisi gibi oyuncu olan biriyle nişanlıdır. Ancak New York'ta izlediği bir oyun sırasında tanıştığı oyunun yönetmeni Charlie tüm hayatını değiştirmiştir. Charlie'ye duyduğu aşk yüzünden yaşadığı şehri, nişanlısını ve TV sektöründeki kariyerini geride bırakıp New York'a yerleşir. Orada aynı tiyatroda birlikte çalışmaya başlarlar, sonrasında evlenirler ve Henry doğar. Nicole evlilikleri boyunca hep Charlie'nin seçimlerini yaşamıştır, ara ara Los Angeles'a gidip bir süre de orada yaşamayı hep konuşmuşlar ama hiç gerçeğe dönüştürmemişlerdir. Nicole bir gün Charlie'yle olan ilişkisinde kendisinin var olmadığını hissetmiş ve o gün onu terk etmiştir. Aynı zamanda Charlie'nin sahne yönetmeni ile yattığını düşünmektedir. Oyun provalarına ara verildiğinde Charlie Henry'yi görmek için Los Angeles'a gelir. Burada Nicole kız kardeşi vasıtasıyla Charlie’ye boşanma tebligatını verir. Charlie çok şaşırmıştır, Nicole avukatlar yoluyla bu işi çözmenin daha kolay olacağını söyler. Charlie'nin de kendine avukat tutmaktan başka çaresi kalmamıştır ve en az Nora kadar saldırgan bir boşanma avukatı olan Jay ile tanışır ancak onun bu saldırgan tavrı 
Charli'yi rahatsız etmiştir, ayrıca ücreti de çok yüksektir. Bu meseleyi biraz erteleyip oyun çalışmaları için New York'a geri dönen Charlie Nora'nın arayıp bir avukat tutmaz ve yolladıkları celbe cevap yazmazsa oğlunun tam velayetinin Nicole'e geçeceğini söylemesi üzerine tekrar Los Angeles'e gelerek daha uzlaşmacı tavırlı bir avukat bulur. Bütün bu süreçler için Charlie Los Angeles'ta bir ev tutmak zorunda kalır. Çünkü Charlie'nin tüm ısrarlarına rağmen TV dizisi beğenilen Nicole'ün New York'a dönmeye hiç niyeti yoktur.

İkili kendi aralarında anlaşamayınca boşanma mahkemeye taşınır. Oldukça çirkin ve kişisel suçlamaların karşıııklı havada uçtuğu (Nicole'ün alkol alışkanlığı ve Charlie'nin gönül ilişkisi gibi) bir dava sonucunda hakim iki ebeveynin de bir süre gözlenmesine karar verir. Mahkemeden sonra olayların bu noktaya gelmesinden rahatsız olan Nicole Charlie'nin dairesine gider. Aralarında büyük bir tartışma çıkar. Evlilikleri boyunca birbirlerine itiraf edemedikleri tüm kötü düşünceleri bu kavga sırasında ortaya dökerler. Sonunda Charlie büyük bir duygusal kırılma yaşar. Nora'nın dizlerine kapanarak ağlar ve özür diler.

Charlie Henry ile vakit geçirirken ona bir şaka yapmak ister ancak bu şaka sırasında çok derin bir şekilde elini keser. Tam bu esnada onu değerlendirmekle görevli olan kamu görevlisi gelir. Charlie elindeki kesiği saklamaya çalışır ve bu esnada oldukça gergin ve tuhaf davranır. İlk değerlendirme görüşmesi oldukça kötü geçer. Sonunda Charlie ve Nicole velayet konusunda anlaşırlar. Nicole velayetin neredeyse tamamını almıştır. Henry de onunla birlikte Los Angeles'ta yaşacaktır. Aradan bir zaman geçtikten sonra Charlie onları ziyarete gelir. Nicole yeni biriyle görüşmektedir, Emmy'ye aday olmuştur ve hep olmak istediği ama Charlie'den dolayı cesaret edemediği yönetmenlik için de ilk teklifini almıştır. Charlie Los Angeles'ta bir oyun yönetmesi için teklif aldığını bir süre oralarda olacağını söyler. Henry oynarken Nicole'ün arabulucuda okumayı reddettiği mektubunu bulur, babasından okumasını ister. Charlie mektubu olur ve ağlar. Nicole onun günü olmamasına rağmen Charlie'ye Henry'yi alabileceğini söyler, Henry ve Charlie uzaklaşırken Nicole gelip Charlie'nin çözülmüş olan ayakkabı bağcığını bağlar.

\section{Karakterler}

\section{Nicole}

Sevdiği adam için kendi hayallerinden ve hayatından vazgeçen, anne ve iyi eş olmanın kendisine yeteceğini düşünen kurban konumunda bir kadınken hayatının kontrolünü eline alıp, kendi seçim ve isteklerini yaşamaya karar veren Nicole, kendi değerini ve gücünü keşfeder. Bu noktadan sonra bir aydınlanma yaşarken artık çevresindekilerin ne düşündüğünü değil yalnızca kendini dinlemeye başlar. Bu süreçte geçmişte yaptığı seçimlerin kendi seçimleri olmadığını, her zaman Charlie'nin seçimlerine ayak uydurduğunu, onun tiyatrosunda çalışmış, onun evine taşınmış, onun beğendiği mobilyaları almış, onun sevdiği şehirde kalmış, kısacası onun hayatını yaşamış olduğunu fark eder. Artık ipleri eline almaya ve kendi hayatını yeniden inşa etmeye 
karar verir. Bunu yaparken de hem Charlie'ye ve hem de oğlu Henry'ye en az zarar verecek çıkış yolunu bulmaya çalışır. Nicole mesleğine aşık bir oyundur, insan ilişkileri iyidir ancak Charlie'nin hayatını yaşaması onun içine kapanmasına ve kendi potansiyelini geri plana itmesine neden olmuştur. Bugüne kadar benliği, kimliği, hatta oyunculuğu bile sadece Charlie üzerinden bir değer kazanırken artık kendisi olarak bir şeyler yapmaya kararlıdır. Bu kararı verene kadar Nicole hep kendini Charlie üzerinden tanımlar. Hatta en büyük arzularından biri olan yönetmen olma isteğini bile bu sebeple ertelemiştir çünkü Charlie gibi dahi bir yönetmeninin arada sırada söylediklerini uygulamasının bile ona yettiğini, bunun bir onur olduğunu düşünmüştür. Nicole boşanmaya karar verdikten sonra Charlie'nin tüm dalga geçmelerine rağmen kendisine gelen TV dizisi teklifini kabul eder. Bu aslında onun değişiminin de en büyük ve ilk adımıdır. Çünkü Nicole'ün özgürleşmesi ancak kendini Charlie'den koparması yani Charlie üzerinden değil kendi varlığı üzerinden kendine bir değer oluşturması ile mümkündür.

\section{Charlie}

Charlie New York'taki küçük tiyatrosuna ve yaptığı işe saplantı derecesinde tutkun, yetenekli bir tiyatro yönetmenidir. Tiyatrodaki tüm kararları verme alışkanlığını evlilik hayatına da aynen sirayet ettirmiş, Nicole'ü kendinin bir devamı olarak gören, baskın bir karakterdir. Çok genç yaşta evlenmeleri ve o dönemde Nicole'e göre kariyerinin geride olması, Charlie'nin zamanla kazandığı üne rağmen istediği her şeyi yaşayamamasına neden olmuştur. Büyük kavgaları sırasında Charlie yaşayabileceği çok şey varken Nicole için hepsinden feragat ettiğini dile getirir. Kendini ilişkide kurban olarak görmektedir. Ancak boşanma olayıyla ve Nicole'ün duygularıyla yüzleşince kendi bencilliğinin de yavaş yavaş farkına varır. Özellikle filmin en sonun Nicole'ün onunla ilgili yazdığı olumlu şeyleri okuduğunda derin bir pişmanlık hisseder. Charlie oğlunun bakımıyla ilgilenen, ona önem veren, hatta şehir değiştirme söz konusu olduğunda tüm hayatını oğlu için geride bırakabilecek düzeyde ilgili bir babadır. Oğlunun ihtiyaçları söz konusu olduğunda bunu karısının görevi olmak görmez, ilgiyle ve isteyerek oğluyla ilgilenir. Charlie Nicole'e göre duygularını daha kolay belli eden, daha kırılgan ve duygusaldır. Film boyunca birçok kez duygusal patlamalar yaşar ve bu patlamalar sonucu ağlar.

\section{Nora}

Nora Los Angeles'lı güçlü, kararlı, iktidar sahibi bir kadın avukattır. Genellikle boşanma davalarına bakan ve kadın haklarını savunan biridir. Kendisi de olaylı bir boşanma sürecinden geçmiş olan Nora bu sebeple hem müvekkillerini çok iyi anlar hem de olaylara hep kadın bakış açısıyla yaklaşır. Ofisine ilk geldiğinde Nicole hep Charlie'yi övüp sürekli onun düşüncelerinden bahsederken Nora Nicole'e değerli olanın o olduğunu, iyi bir oyuncu olduğunu, Charlie'nin ona sahip olduğu için şanslı olduğunu söyler ve onun kendi değerinin farkına varmasını sağlar. Aynı zamanda Nicole'ü kendi seçimlerini yaşama sırasının geldiğine, nerede yaşamak istiyorsa orada yaşaması gerektiğine ikna eder. Nicole devamlı Charlie'nin ne isteyeceğinden söz ederken Nora 


\section{MEDIAJ}

"Bizi ilgilendiren senin isteklerin!" der ve onu kendi isteklerini dile getirmesi konusunda cesaretlendirir. Nora aynı zamanda Nicole'e yeterince fedakarlıkta bulunduğunu fedakarlık sırasının Charlie'de olduğunu söyler. Boşanma süreci boyunca oldukça saldırgan ve agresif bir tavırla her ne olursa olsun Nicole'ün haklarını kazanmaya çalışır.

\section{Kadın ve Mekan}

Kadının yerinin özel alana hapsedilmesi ve kadının kamusal alandan dışlanması bağlamında içeriğe baktığımızda filmde ana kadın karakter olan Nicole'ün eril söylemin kadının ana yerlerinden biri olarak tanımladığı mutfağa sadece bir kez annesinin evinde gittiğini görüyoruz. Orada da amacı mutfakla ilgili bir iş yapmak değil Charlie'ye boşanma haberini vermektir. Nicole film boyunca birçok kamusal alanda, çalıştığı tiyatroda, dizi setinde, avukat ofisinde, annesinin evinde, mahkeme salonunda, restoranda, psikolog muayenehanesinde, metroda, cadılar bayramı partisinde gösterilmiştir. Evde olduğu sahnelerde ise hiçbir zaman ataerkil ideoloji tarafından kadının görevi olarak empoze edilen ev işi, çocuk bakımı gibi şeylerle ilgilenmez. Tam tersine ikilinin Henry’nin bakımıyla ilgili sahnelerinde, örneğin üçünün birlikte yatakta yatıp Henry'yi uykuya hazırlamalarında Henry'ye kitabı okuyan da, onun yanında yatan da ve sonrasına gece boyunca uyandığında onunla ilgilenen de Charlie'dir.

\section{SONUÇ}

Toplumsal cinsiyet kodları toplumdan, toplumsal yaşamdan ve dolayısıyla sanattan bağımsız değildir. Günümüzde kitle iletişiminin en güçlü araçlarından olan sinema endüstrisi var olduğu günden beri ataerkil bir yapıyla eril söylemi tekrarlayan, pekiştiren filmler üretmeye devam etmiştir. Özellikle klasik anlatı diye tanımlanan Hollywood filmleri kadına ve kadın karakterlere sadece dolgu malzemesi, güzel, arzulanmaya ve görülmeye değer nesne muamelesi yapmıştır. Bu filmlerin ana film kişileri her zaman baskın erkek karakterlerden oluştu, erkeklerin hikayesini erkek seyircileri hedefleyerek erkeklerin bakış açısıyla anlatmıştır. Burada kadın ne hikayesi işlenen ne de izleyen olarak bir öneme ya da yere sahip değildir. 60'larla birlikte her alanda sorgulanmaya başlanan toplumsal cinsiyet olgusu elbette sinema eleştirisine de etki etmiştir. Feminist film eleştirisi film anlatımındaki ataerkilliği teşhir ederek daha sonra yapılacak filmlere yol göstermiş, film yapımcılarının, yönetmenlerin ve senaristlerin bakış açılarını genişletmiştir (Büker, 2010, s.205).

Günümüzde dünyanın en büyük film üreticilerinden biri olan Netflix ana akım, yani ataerkil, beyaz adam hikayelerinin karşısına siyahilerin, göçmenlerin, eşcinsellerin, kadınların ya da bunlardan birden fazlasının kombinasyonu olan karakterlerin hikayelerini anlatan filmler üreterek alternatif bir anlatım yaratmaya çalışmaktadır.

Bu filmler arasında kadını merkeze alan, kadın sorunlarına ve konularına kadın bakış açısıyla yaklaşanlar hem fazlaca üretilmeleri hem de yüksek nitelikte olmaları sebebiyle özellikle dikkat 


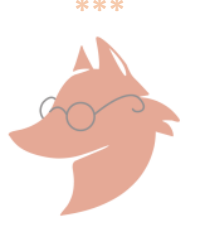

Cilt: 04 - Sayı: 01

çekmektedir. Bu filmlerden gerek aldığı ödüller, gerekse hikaye anlatmadaki gerçekçiliği bakımından ön plana çıkan "Marriage Story" de merkezine Nicole isimli bir kadın karakteri alan ve o kadının boşanma sürecinde yaşadıklarını yansıtan bir filmdir. Filmde ataerkil anlayışın toplumsal cinsiyet rolleri bağlamında kadına yüklediği hemen hemen hiçbir rol Nicole'e yüklenmemiştir. Klasik anlatı sinemasının klasik kurban kadın karakteri değildir Nicole. Nicole tam da feminist sinemanın görmek istediği kendi yazgısının kontrolünü eline alan, tüm engellere rağmen kendi seçimlerini yaşayan, özgürleşen, bağımsız kadındır. Çünkü Nicole sistemin istediği gibi ne olursa olsun aileyi bir arada tutma görevini üstlenen, her şeyden önce ve önemli olarak "anne ve eş" olma rolünü reddetmiş, Charlie'yi, işini, yaşadığı şehri bırakarak her şeyi baştan başlatmaya cesaret etmiştir. Burada Nicole artık kesinlikle bir kurban değildir. Bunları yaparken aynı zamanda daha önceki hayatında kurban rolünü üstlendiğinin de farkına varır ve feminist sinemanın yapmaya çalıştı̆̆ı gibi kendi haklarının, isteklerinin, hayallerinin, arzularının, kısacası kendinin farkına varan bir kadına dönüşür.

Başrol oyuncusu Scarlett Johansson her ne kadar sinemada birçok kez klasik anlatının klasik arzu nesnesi, görülmeye değer kadını oynamış olsa da bu filmde canlandırdığı Nicole karakteri film boyunca bir kez bile kadınlığını öne çıkartacak biçimde davranmaz veya giyinmez. Film boyunca karakter kısacık saçları, kendine birkaç beden büyük gelen erkeksi gömleklerle, düz gündelik ayakkabılarla, makyajsız ve bakımsız bir halde yansıtılır. Filmdeki cadılar bayramı partilerine bile David Bowie, ve John Lennon kılığında, yani erkek kıyafetleriyle katııır. Bu anlamda filmde tam bir feminist tutum söz konusu olduğunu gözlemliyoruz. Oldukça çekici ve güzel bir kadın Johansson filmde bir kez bile bu özellikleriyle gösterilmemiş, arzu nesnesi konumuna indirgenmemiştir.

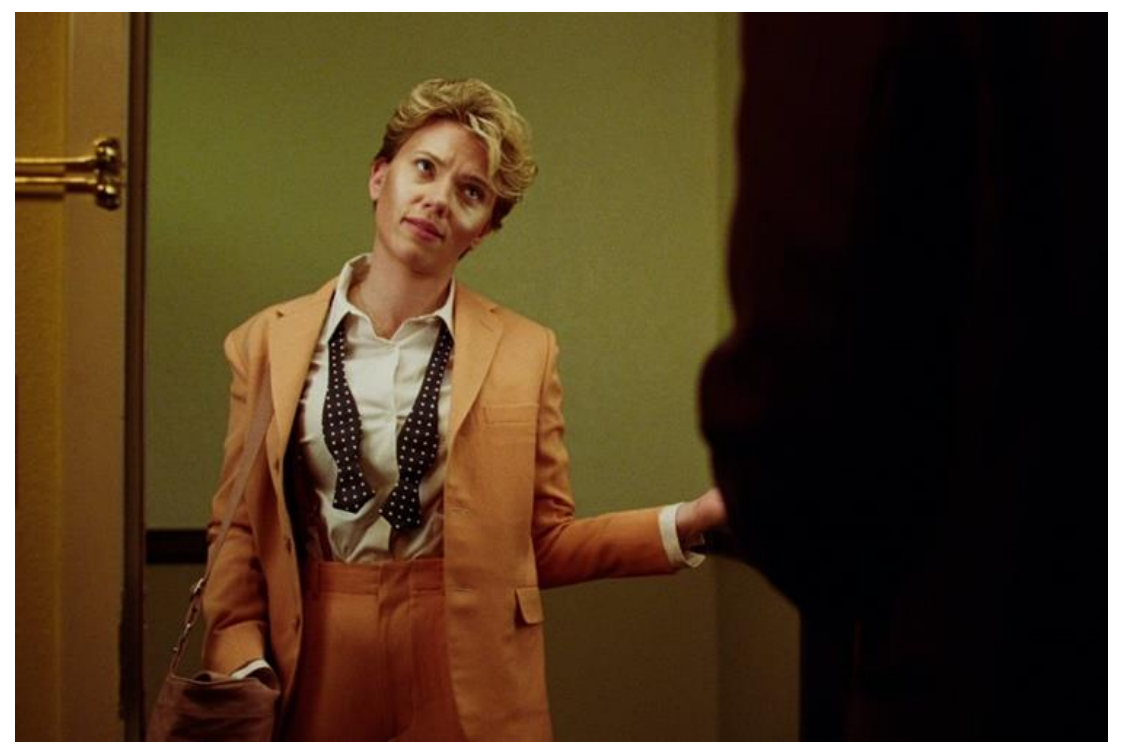

Görsel 1. Noah Baumbach’ın Marriage Story Filmi Cadılar Bayramı Sahnesi 


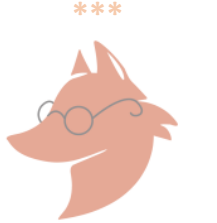

Ataerkil sinemanın söylemlerinden bir diğeri kadının duygusal, erkeğinse ussal olduğudur. Oysa Marriage Story filminde Nicole her ne kadar duygusal yıkımlar yaşasa da bunları genelde belli etmez, hayatıyla ilgili ussal kararlar alır. Tam tersine Charlie ise birçok kez büyük duygusal duygusal tepkiler verir ve bunları göstermekten de çekinmez. Özellikle filmle özdeşleşmiş meşhur kavga sahnesinde öyle büyük bir duygusal kırılma yaşar ki Nicole'ün dizlerine kapanıp uzunca bir süre ağlar. Burada ayakta durmaya bile gücü kalmamıs olan Charlie'ye karşın yaşadığı bu çok zor durumda bile daha güçlü olan ve ayakta kalan yine kadın karakter Nicole'dur.

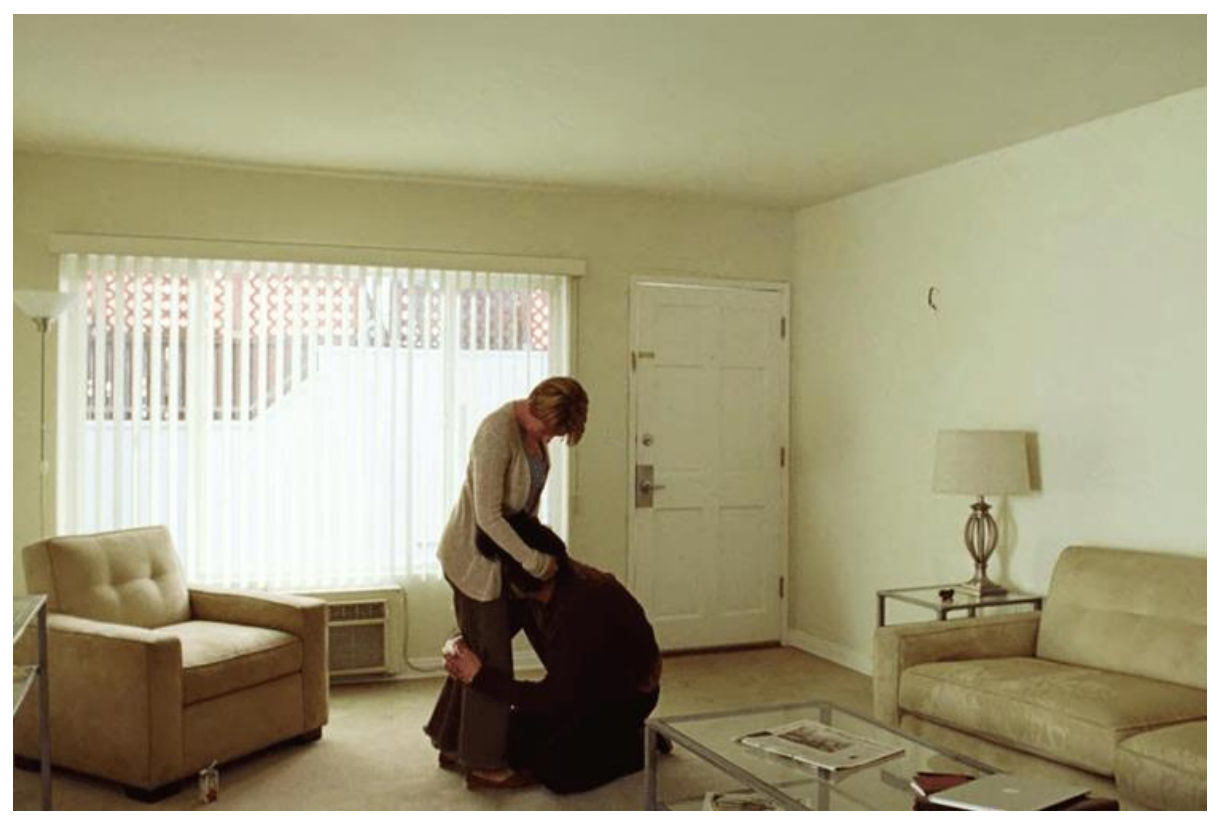

Görsel 2. Noah Baumbach'ın Marriage Story Filmi Kavga Sahnesi

Filmde feminist söylemi en güçlü şekilde dile getiren karakter hiç şüphesiz ki Nora'dır. Başarılı, tuttuğunu koparan, kendinden emin, bağımsız, kadın hakları savunucusu Nora, inandıklarını kendi hayatında uygulamakla kalmaz temsil ettiği kadın müvekkillerin de kendi kurban olma durumlarını fark etmeleri ve hayatlarının kontrolünü ellerine almaları için onlara kılavuzluk eder. Bu bağlamda Nora filmde feminizmin hakkını arayan, özgürleşen ve böylece eşitliğini kazanan kadın modelini temsil etmektedir. Ve Nora yine bu bağlamda feminist söylem ekseninde "kız kardeşlik" görevini yerine getirmiş ve kadın kadına dayanışmanın temsili olmuştur. Aynı zamanda Nora feminist söylemin toplumsal cinsiyet eleştirisinin de sözcüsüdür. Özellikle karakterle özdeşleşmiş olan meşhur monoloğu adeta bir feminist manifesto gibidir:

"Kusurlu bir babayı kabul edebiliriz. Dürüst olalım, iyi bir baba fikri şunun şurasında 30 yıl önce icat edildi. Ondan önce babaların sessiz, dalgın, güvenilmez ve bencil olması bekleniyordu ama şimdi farklı olmalarını istiyoruz. Ama belli bir seviyede onları kabulleniyoruz. Onları yanlışlarıyla seviyoruz. Ama insanlar aynı 


\section{MEDIAJ}

duyguların annelerde olmasını kesinlikle kabul etmiyor. Bunu ne yapısal olarak ne de ruhsal olarak kabul edebiliyoruz çünkü kökenimizde Meryem Ana var. İsa'nın annesi ve o mükemmel. O doğum yapan bir bakire. O çocuğunu kararlılıkla destekliyor ve öldügünde bile bedenini bırakmıyor. Baba ise ortalarda yok. Üreme işini bile yapmamış ve cennette. Tanrı ve baba ama Tanrı ortalarda bile görünmemiş. Yani sen mükemmel olmalısın ve Charlie boktan olsa da bir önemi yok. Hep farklı daha yüksek bir standarda tabi tutulacaksın."

Nora karakteriyle özdeşleşmiş olan bu monolog, kadının her daim mükemmel anne olması, babanın ise çocuğun yetiştirilme sürecinde hiçbir görev ve sorumluluğunu yerine getirmese bile babalığının sorgulanmaması üzerine oldukça çarpıcı bir tespittir. Bu monolog toplumsal cinsiyet kalıplarının kadını sadece erkekle olan ilişkisi ve anneliği üzerinden konumlandıran, ideal kadın kodlamasına bir eleştiridir. Burada aynı zamanda Nora toplumun erkeği kayırmasını ve onu hatalı ve eksik bile olsa mazur görülmesini bir haksızlık, eşitsizlik olarak tanımlamaktadır. Bu tanım ve yargılar feminist eleştirinin en yoğun olarak ele aldığı kadının ideal eş ve anne olarak dayatılması ve erkeğin olumsuz ve eksik özelliklerinin bile haksız bir biçimde sürekli olumlanması söylemiyle birebir örtüşmektedir.

Ana kadın karakter Nicole'ün özel alanlara hapsedilmemesi, her türlü kamusal alanda yer alması, özel alanlarda bulunduğu sahnelerde ise burada annelik ya da iyi eş olma görevleriyle (çocuğa bakmak, yemek ya da temizlik yapmak gibi) gösterilmemesi, feminist eleştirinin kadının özel alanlara hapsedilip kamusal alanlardan soyutlanması eleştirisine paraleldir. Filmde kadın özel alanda olduğu zamanlarda dahi ev işi, temizlik, yemek yapmak ya da çocuğa bakmak gibi yine toplumsal cinsiyet rollerinin dayattığı görevleri yaparken gösterilmez.

Marriage Story filmi erkek bir yönetmen ve senarist tarafından üretilmiş olmasına rağmen ataerkil ideolojinin kadınlara yüklemeye çalıştığı toplumsal cinsiyet rollerini yeniden üretmemiş, güçlü, savaş̧̧ı ve çalışan kadın karakter temsilleri ile ana akım sinemadan farklı olarak kadını filmin öznesi durumuna getirmiş, kadına yüklenmeye çalışılan toplumsal cinsiyet rollerini eleştirmiş ve eril bir bakış açısı yerine eşitlikçi bir bakış açısı ile evlilik ve boşanma kavramlarına yaklaşmıştır.

\section{KAYNAKÇA}

Adanır, O. (2006). Kültür politika ve sinema. İstanbul: +1 Kitap.

Baumbach, N. (Yapımcı\& Yönetmen). (2019) Marriage Story. ABD: Netflix.

Beauvoir, S. (1952). The second sex. New York: Bantham. 


\section{MEIDIAJ}

Berger, J. (2014). Görme biçimleri. İstanbul: Metis Yayınları.

Berktay, F. (2013). Toplumsal cinsiyet çalışmaları içinde; yeni feminizm ve kızkardeşlik. Eskişehir: Anadolu Ünv. Yayınları.

Büker, S. (2010). Sinema: tarih-kuram-eleştiri, feminist ve psikanalitik eleştiriye giriş. Istanbul: Kırmızı Kedi Yayınevi.

Cook, P. Bernink, M. (2005). Feminist film theory. Londra: The Cinema Book. Spectator.

Desjardings, M. (1988). May:68 Feminism and beyond, Spring 1988, Los Angeles:

IMDB. Marriage Story. (2019). Erişim: 15.01.2021,

https://www.imdb.com/title/tt7653254/?ref_=ttpl_pl_tt

Johnston, C. (1973). Women's cinema as counter cinema. Screen Pamplet.

Kuhn, A., Radstone, S. (1991). Women in film: an international guide. New York: Ballantine Books.

Mulvey, L. (1975). Visual pleasure and narrative cinema. Screen Autumn.

Netflix. Hakkında. Erişim: 05.01.2021, https://about.netflix.com/en

Neuman, W.L. (2012). Toplumsal araştırma yöntemleri: nicel ve nitel yaklaşımlar. Yayın Odası. İstanbul.

Randolf, M. (2019). That will never work. New York: Little Brown and Company.

Ryan, M. Lenos, M. (2012). Film çözümlemesine giriş. Ankara: De Ki Basım Yayım.

Sevim, A. (2005). Feminizm. İstanbul: İnsan Yayınları.

Sim, G. (2016). Individual disruptors and economic gamechangers: Netfix, new media and neoliberalism. Bloomsbury Academic\& Professional.

Smelik, A. (2008). Feminist sinema ve film teorisi ve ayna çatladı. İstanbul: Agora Kitaplığı.

Ögüt, H. (2009). Cogito Sayı: 58/ Bahar. İstanbul: Yapı Kredi Yayınları.

Vielen, D. H. (2018) The Netflix effect? on updating the cinematic apparatus theory, Holland: Faculty of Humanities. 